\title{
姿勢が着衣熱抵抗值に及ぼす影響に関する研究 THE INFLUENCE OF POSTURES ON THERMAL INSULATION OF CLOTHING
}

\author{
藏 澄 美仁*1, 堀口明子*2, 坂 本 英彦*3, 松原 斎 樹*4 \\ Yoshihito KURAZUMI, Akiko HORIGUCHI, Hidehiko SAKAMOTO \\ and Naoki MATSUBARA
}

\begin{abstract}
The purpose of this paper is to clarify the influence of postures on the thermal insulation of clothing and the clothing area factor. Clothing area factors were measured by using the photographic method. Experiments were carried out to evaluate the effects of posture and operative temperature on the thermal insulation of clothing. Thermal insulations of clothing were measured by using a thermal manikin varying postures. Five common body postures were used for these measurements: standing, chair sitting, cross-legged sitting, leg-out sitting and supine positions. It was clarified that measurements from all azimuth angle directions of the human body and different altitude angle directions were indispensable to determine the clothing area factor by using photographic method. It acquired that the posture affects the clothing area factor. The thermal insulation of clothing increased significantly with operative temperature. It acquired that the environmental temperature affects the thermal insulation of clothing. It was clarified that it was absolutely indispensable for evaluating the thermal environment to use the thermal insulations of clothing in postures.
\end{abstract}

Keywords: posture, clothing area factor, thermal insulation, thermal environment, thermal manikin, evaluation 姿勢, 着衣面積増加率, 熱抵抗, 温熱環境, サーマルマネキン , 環境評価

\section{1. はじめに}

居住空間の温熱環境設計をする場合には、その空間に相応した設 計基準值が必要となる。温熱環境の設計基準值は温熱環境刺激に該 当する物理的要因とそれに対する人体反応との関連付けをおこなっ た数值であることが不可欠である。物理的な要因は多くあるが、通 常は、体感温度を考慮した人体の熱収支より導かれる温熱環境指標 を環境刺激の代表值として用いている。人体の熱収支量は人体と周 囲環境との間の対流や放射、伝導、蒸散による経路別に算定される。

従来の温熱環境設計基準值は、労働空間や作業空間である工場 やオフィス空間での温熱環境を対象に求められてきたために、立 位や椅座位の姿勢に限定されている。しかし、日本における居室 空間では、居住者の姿勢はさまざまである。松原ら (2000) ${ }^{11}$ や大 和ら $\left(2005 \mathrm{a}^{2)}, 2005 \mathrm{~b}^{3)}\right)$ は、住宅の居室での居住者の姿勢は投げ足 位などの床座位が多いという実態をアンケート調査により明らか にしている。そして、藏澄ら (19974), 1998a $\mathrm{a}^{5)}, 1998 \mathrm{~b}^{6)}, 1998 \mathrm{c}^{7)}$, $1999 a^{8)}, 1999 b^{9)}, 1999 c^{10)}, 2000^{11)}, 2003^{12)}, 2004 a^{13)}, 2005^{14)}$ ) や Kurazumi et al.(2004b $\left.{ }^{15)}, 2004 \mathrm{c}^{16)}\right)$ は日本人の居室空間での姿 勢に着目し、人体の熱収支や人体の温熱刺激に詨する反応が、姿勢 の違いにより明確な差があることを被験者実験により明らかにして
いる。したがって、温熱環境の設計基準值を検討するためには姿勢 の違いを把握することが不可欠となる。

これら一連の研究では裸体を対象にしているが、現実の空間では 衣服を着用した状態であるので、着衣を対象とした研究が必要であ る。人体の熱収支を考える場合には、裸体を基準として衣服の熱的 な効果を着衣量として取扱っている。通常、着衣は人体と周囲環境 との間の断熱層となり、熱抵抗として取扱われている。この熱抵抗 は、着衣外表面と皮虐表面との間に存在する空気層の熱抵抗も含め ている。必然的に、体表面どうしが接触する部分や体表面と椅子面・ 休面などとが接触する姿勢では、圧迫による衣服内空間の空気層が 非接触面とは大きく異なるので、着衣熱抵抗値も姿勢別に把握する ことが要求される。

着衣熱抵抗值は体表面から着衣外表面までの間の空気の性状の 影響を受ける。これは、着衣の組合わせ (Seppanen et al., 1972

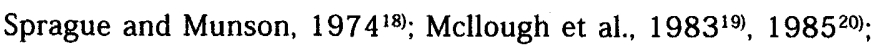

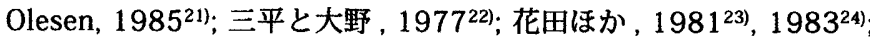
花田と三平，198525); Mihira and Hanada, 199126); 佐古井ほか， $2000^{27)}$ ) や着衣のゆとり(花田, 1979b ${ }^{28)}$; 岩崎と田村, 1985 29 ,

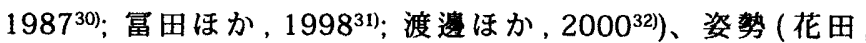

\footnotetext{
*1 広島国際大学社会環境科学部住環境デザイン学科 教授・博士 (工学)

*2 タカラスタンダード(侏)

*3 兵庫県立大学大学院環境人間学研究科 大学院生

*4 京都府立大学人間環境学部環境デザイン学科 教授・工博

Prof., Dept. of Socio-Environment Design, Hiroshima International University, Dr. Eng.

Takara Standard Co., Ltd.

Graduate Student, Graduate School of Human Science and Environment, University of Hyogo

Prof., Dept. of Environmental Design, Kyoto Prefectural University, Dr. Eng.
} 
$1979 \mathrm{a}^{33)}, 1979 \mathrm{~b}^{28)}$; Olesen et al., 1982 ${ }^{34)}$; 西村ほか, 19943); 大 和ほか, 2003 ${ }^{36)}$ )、気流(渡邊ほか，1999) ${ }^{37}$ 、気温(渡邊ほか， 1999) ${ }^{37)}$ などに関連する。しかし、気流や気温、姿勢などがクロ 值に与える影響に着目した研究は少ない。

着衣熱抵抗値は被験者実験により人体の熱収支より求める方法 やサーマルマネキンを用いる方法、着衣の組合わせや重さなどより 算出する方法、着衣の組合わせや単品着衣の熱抵抗值の資料より求 める方法などにて算定される。

着衣の組合せなどの着装状態が変わる度に随時熱抵抗值を求め る被験者実験やサーマルマネキンを用いる方法は実用性には欠け る。したがって、一般的には推定式や資料(花田ほか, 1981 23 ), 198324); Olesen, 198521); McCllough et al., 198520); Sprague and Munson, 1974 ${ }^{18)}$; 佐古井ほか, 200027) より着衣熱抵抗値が求め られている。しかし、これら算定値の根拠となっているデータは立 位姿勢のサーマルマネキンを用いた実験によるものである。

サーマルマネキンを用いて姿勢の違いが着衣熱抵抗值に与える 影響を検討した研究には花田 $\left(1979 \mathrm{a}^{33)}, 1979 \mathrm{~b}^{28}\right)$ や Olesen et

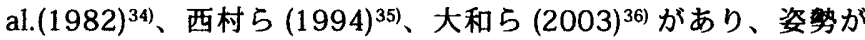
強く着衣熱抵抗值に影辢していることを示している。まず、花田 $\left(1979 a^{33)}, 1979 b^{28)}\right)$ は、立位と腕拳上・開脚位、椅座位、投げ足 位の姿勢には着衣熱抵抗値に逗いがあることを示している。しか し、マネキンの局所での着衣熱抵抗值の比較のみで、全身について の検討はおこなっていない。次に、Olesen et al.(1982) 座位の着衣熱抵抗値は立位の場合よりも 8 18\% 程度低くなること を示している。しかし、設定温熱環境条件は作用温度で $24^{\circ} \mathrm{C}$ に限 定されている。次に、西村ら $(1994)^{35)}$ は、姿勢の変更にともなう 着衣のずれあがりが着衣熱抵抗值の変化に大きく影签していると している。しかし、姿勢の違いが着衣面積增加率に影辢を及ぼすと 推察されるが、着衣面積増加率を実測しておらず、立位と椅座位の 着衣面積増加率は等しい値を代用している。着衣のずれあがりによ る着衣面積増加率の差は着衣熱抵抗值の算出に考慮できていない。 そして、大和ら $(2003)^{36)}$ は、着衣面積増加率と着衣熱抵抗值には 姿勢の違いがあることを明確にしている。しかし、実測值に大きな 分布があり、検証の必要がある。

前述のように、日本人の居住空間では、体表面と椅子面や床面な どとの接触による圧迫により、衣服内空間の架気層が非接触面とは 大きく異なる。必然的に、着衣面積増加率は姿勢により大きく変化 する。したがって、着衣熱抵抗值を算定するには、着衣による伝熱 面積の増加を考虑する必要があり、その増加割合に相当する着衣面 積增加率を実測することが不可久である。

着衣面積増加率に関する研究は写真撮影による方法と展開した 着衣の面積測定をする方法を用いたものがある。いずれも着衣熱抵 抗を求める研究の過程で実測されており、着衣面積増加率のみを研 究対象としているものは極めて少ない。

写真撮影による方法には普通写真レンズを用いた投射面積によ るもの (Fanger, 1970 ${ }^{38)}$; Seppanen et al., 1972 ${ }^{17) ; ~ S p r a g u e ~ a n d ~}$ Munson, 1974 ${ }^{18)}$; Olesen et al., 1982 ${ }^{34)}$; Mcllough et al., 1983 ${ }^{19}$, 198520); 冨田ほか, 1998 ${ }^{31)}$; 大和ほか, 2003 ${ }^{36)}$ ) と正射影魚眼レン ズを用いた投射面積によるもの (Kakitsuba et al., 1987 ${ }^{39}$; 垣鍔と 鈴木，199740); 宮本と冨田，200041) がある。
着衣の面積測定をする方法には着衣の展開図によるもの (冨田 ほか，199831); 佐古井ほか，200027) と着衣の展開図による面積と 着衣の重なりや組み合わせ方を考慮したもの(渡邊ほか, 199937), 200032) がある。

着衣の組合せなどの着装状態が変わる度に随時実測をする 場合を除いて、Sprague and Munson(1974) ${ }^{18)}$ や Olesen et al.(1982) ${ }^{34) 、 M c l l o u g h ~ e t ~ a l .(1983) ~}{ }^{19)}$ の着熱抵抗值が説明変数と なっている線形式で表現された算定式により着衣面積増加率は求 められている。また、着衣のゆるみ度に関連する被服下気候の気 積が説明変数となっている線形式で表現された算定式 (Kakitsuba et al., 1987) ${ }^{39)}$ も着衣面積增加率を求める際に用いられている。こ れらの算定式の根拠となっている着衣面積増加率のデータは、全 身の写真投影画像が前後・左右対称であると見做し、全身の前後・ 左右の一方のみに限定した写真撮影法によるものであるが、大和 ら (2003) ${ }^{36)}$ は姿勢を考慮した場合には人体を囲うように全周にわ たって実測をする必要性を示している。

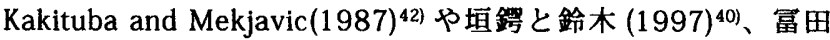

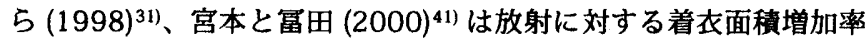
を示している。まず、垣鐶と鈴木 $(1997)^{40)}$ は着衣熱抵抗值を用い た線形式による着衣面積増加率と放射に対するものとは異なるこ とを示している。そして、冨田ら $(1998)^{31)}$ は着衣の展開面積によ る着衣面積増加率と放射に対するものとは異なることを示してい る。藏澄ら (2003) ${ }^{12)}$ や Kurazumi et al.(2004c) ${ }^{16)}$ は対流による伝 熱面積を実測して放射による伝熱面積との違いを明確にしている か、着衣面積増加率についても同様なデータが得られることが推察 される。

以上より、姿勢が衣服内空間の空気層の熱抵抗に顕著な影響を及 ぼすことは明らかであるが、姿勢によるその空気層の変化を着衣面 糟增加率へ反映させている研究は稀有である。

そして、着衣と体表面との間に存在する気道を移動する空気の挙 動は、気温と皮局温との温度差に影辢されるので、生活空間の実 態に相忘した室温条件で着衣熱抵抗值を検討する必要がある。現 実の生活空間では室温は快適な温度でないことが多い。住宅の居室 を対象とした多くの室温の実態調査では、居住者の習慣や住戸種別 などの要因により室温は大きな分布を示している。冬季において は、快適な温度域よりも低温で生活している場合が多いことを松原 と澤島 $(1996)^{43)}$ や坊垣ら (1998) ${ }^{44)}$ が指摘している。したがって、 着衣熱抵抗值の実測には快適な温度条件のみではなく、低温域での 測定が不可欠である。しかし、Olesen et al.(1982) ${ }^{34)}$ は作用温度を $24^{\circ} \mathrm{C}$ に。また、西村ら (1994) ${ }^{35)}$ は作用温度を $26^{\circ} \mathrm{C}$ に設定しており、 いずれも低温域での実験をしていない。

そこで、本研究の目的は、姿勢の違いが着衣面積増加率に及ぼす 影響を明らかにする。さらには、着衣熱抵抗值に及ぼす影響を明ら かにすることであり、低温域でも実験をおこなった。

\section{2. 着衣面積増加事}

姿勢の違いが着衣面積增加率に与える影響を明らかにする実測 をおこなった。着衣面積増加率は着衣時のサーマルマネキンの表面 積と裸体時のマネキンの表面積の比とした。 

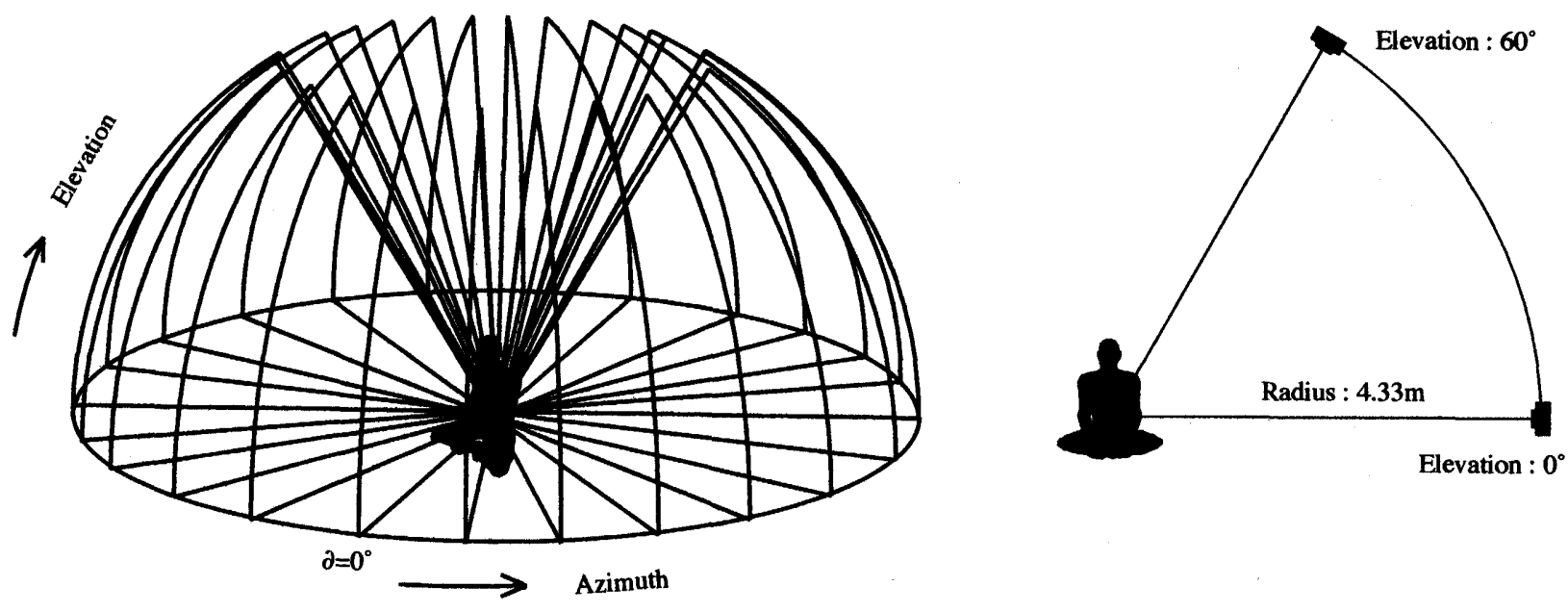

Fig. 1 Cordinate system for measurement of clothing area factor.

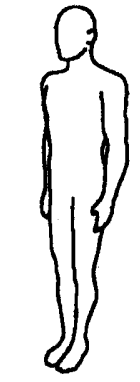

Standing

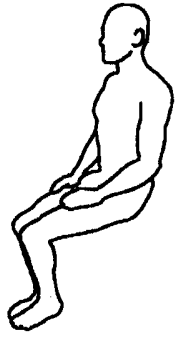

Chair sitting

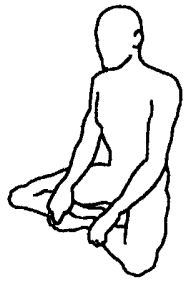

Cross-legged sitting

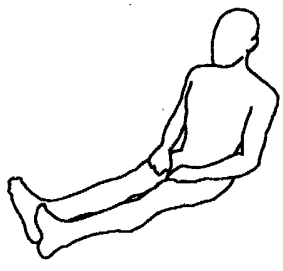

Leg-out sitting

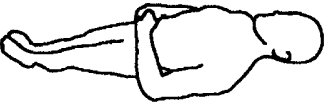

Supine

Fig. 2 Experimental postures.

\section{1 実讨郡面}

着衣面積增加率の実測は、Olesen et al.(1982) ${ }^{34)}$ の写真撮影法を 改良した大和ら $(2003)^{36)}$ の方法を用いた。実測座標の原点は人体 の中心点である滕の奥 $0.1 \mathrm{~m}$ の位置とした。実測座標系を Fig. 1 k 示す。実測位置は仰角と方位角を組合せた 48 点とした。仰角方向 は座標原点から $0^{\circ}$ と $60^{\circ}$ とした。方位角方向はサーマルマネキ ンを取り囲むように正中面を基準とした $15^{\circ}$ 間隔とした。

抽出したサーマルマネキンの射影部分の面積をデジタイザ (Graphtec, KD4310，読み取り精度 $0.025 \mathrm{~mm}$ ) とコンピュータを用 いて自作のプログラムにより面積を求めた。各実測点の着衣面積增 加率は着衣時のサーマルマネキンの投射面積を裸体時のサーマル マネキンの投射面積で除して求めた。

着衣面積増加率の測定には扂と股、膝の関節が可動可能なサ一 マルマネキン (京都電子工業, THM-117S/217S) を用いた。サー マルマネキンの部位ごとの表面積を Table 1 に示す。着衣条件は Table 2 に示す冬季の住宅の居室内における一般的な組み合わせの 着衣 (松原ほか, 20001); 大和ほか，2004 45) とした。サーマルマ ネキンへの衣服の着装には、表面にしわによる折れや重なりが偏っ て分布しないよう十分に留意した。なお、通常の生活実態を考慮し、 設定姿勢に移動させる際に発生する着衣のしわや折れ、重なりな どは成り行きとした。加えて、実測中には衣服の変更はおこなわず、 着衣の状態は全ての姿勢条件を通して一定とした。実測は、Fig. 2 に示す立位、椅座位、胡座位、投げ足位、仰卧位の姿勢別におこな
Table 1. Profile of thermal manikin

\begin{tabular}{lcc}
\hline Region & Surface area $\left(\mathrm{m}^{2}\right)$ & Surface area ratio \\
\hline Head & 0.119 & 0.078 \\
Upper arm-Right & 0.074 & 0.048 \\
Upper arm-Left & 0.074 & 0.048 \\
Lower arm-Right & 0.052 & 0.034 \\
Lower arm-Left & 0.052 & 0.034 \\
Hand-Right & 0.037 & 0.024 \\
Hand-Left & 0.037 & 0.024 \\
Breast & 0.168 & 0.110 \\
Abdomen & 0.062 & 0.041 \\
Back & 0.190 & 0.124 \\
Lumbar & 0.093 & 0.061 \\
Thigh-Right & 0.108 & 0.071 \\
Thigh-Left & 0.108 & 0.071 \\
Leg-Right & 0.115 & 0.075 \\
Leg-Left & 0.115 & 0.075 \\
Foot-Right & 0.062 & 0.041 \\
Foot-Left & 0.062 & 0.041 \\
\hline Whole body & 1.525 & 1.000 \\
\hline
\end{tabular}

った。

\section{2 实朔栉果拈よび考䋈}

立位、椅座位、胡座位、投げ足位、仰臥位姿勢の着面積增加率の 実測結果をそれぞれ Table 3 に示す。全身の着衣面積増加率の算定 
Table 2. Clothing ensembles of measurements

\begin{tabular}{llc}
\hline Description & Material (\%) & Weight (g) \\
\hline Brief & Cotton (100) & 51 \\
Underpants & Cotton (100) & 153 \\
Long-sleeved shirt & Cotton (100) & 184 \\
Trouser & Cotton (100), Polyester (30) & 424 \\
Sweat shirt & Cotton (100) & 384 \\
Socks & Cotton (100) & 51 \\
\hline \multicolumn{2}{r}{} \\
\end{tabular}

は、ISO $(1995)^{46)}$ の算定方法を全身を取囲む実測点へ拡張した各実 測点の着衣面積增加率を平均した。

各姿勢の着衣面積增加率の結果の平均值は、立位が 1.15、椅座 位が 1.12、胡座位が 1.14、投げ足位が 1.14 、仰卧位が 1.21 とな った。同じ着衣でも、着衣面積増加率は姿勢によって違いが認め られる。垣鋽と鈴木 (1997) ${ }^{40)}$ は、着衣のゆとりに着目して、着衣 面積增加率は衣服下気積に影響することを明らかにしている。本 研究では、姿勢が異なると衣服の折れや重なりによる衣服の表面 性状の変化や衣服内空間の空気層の変化などが影響していると考 えられる。垣鐸と鈴木 $(1997)^{40)}$ の指摘と整合する結果が得られた。 姿勢による着衣面積増加率の違いを ANOVAにより比較した結果は $\mathrm{p}<0.01$ となり、姿勢の違いが強く着衣面積增加率に影籍すること が示された。さらに、Tukey-test の結果は、立位と椅座位、立位 と仰卧位、椅座位と仰臥位、投げ足位と仰臥位、胡座位と仰臥位の 間がそれぞれ $\mathrm{p}<0.01$ を示し、これらの姿勢間には姿勢差の影䈉が 強く認められた。

Olesen et al.(1982) ${ }^{34)}$ は、着衣面積增加率の算出には、全身の写 真投影画像が前後・左右対称である見做し、全身の前後・左右の一 方のみに限定した写真撮影による測定で十分としている。この根拋 は、Fanger et al.(1970) ${ }^{47)}$ が、立位の人体は左右対称で人体を中 心とした点対称の位置からの投射面積は等しいと仮定しているこ とによる。しかし、大和ら (2003) ${ }^{36)}$ は、実測により着衣面積増加 率には左右差および前後差があることを明らかにしている。

各姿勢別に、左右の着衣面積增加率の違いを paired t-test をお こなった。いずれの姿勢とも正中面で対称な位置の実測值に差異が 認められるが、その差は有意 $(p>0.05)$ ではなかった。同様に、前 後の着衣面積增加率の違いを各姿勢別に paired t-test を扔こなっ た。いずれの姿勢とも前額面について対称な位置の実測值に差異が 認められるが、その差は有意 $(p>0.05)$ ではなかった。しかし、目 視による観察の結果では、前額面よりも前方側に着衣のゆとりに よる折れや重なりが認められた。立位の場合には、前額面より前 方の部分が後方の部分と比較して小さい結果となっている。一方、 椅座位の場合には、前顆面より前方の部分が後方の部分よりも大 きい結果となっている。投げ足位の場合には、前後の着衣面積增 加率の違いをANOVAにより比較した結果は $\mathrm{p}>0.05$ となり、有意 な差は認められなかったが、Tukey-test の結果は右前方と右後方 の間が $\mathrm{p}<0.05$ を示し、着衣人体の非対称の影響が強く認められた。 胡座位の場合には、前後の左右の着衣面積増加率の違いを ANOVA により比較した結果は $\mathrm{p}<0.05$ となり、着衣人体の非対称の影響が
Table 3. Results of clothing area factors

\begin{tabular}{|c|c|c|c|c|c|c|c|c|c|c|}
\hline$\partial$ & $\begin{array}{l}\text { Sta } \\
\text { Ele } \\
0^{\circ}\end{array}$ & $\begin{array}{l}\text { ling } \\
\text { tion } \\
60^{\circ}\end{array}$ & & $\begin{array}{l}\text { hair } \\
\text { ration } \\
60^{\circ}\end{array}$ & $\begin{array}{c}\mathrm{El} \\
0\end{array}$ & $\begin{array}{l}\text { s } \\
\text { ion } \\
0^{\circ}\end{array}$ & & $\begin{array}{l}\text { out } \\
\text { tion } \\
60^{\circ}\end{array}$ & & $\begin{array}{l}\text { jine } \\
\text { ation } \\
60^{\circ}\end{array}$ \\
\hline $0^{\circ}$ & 1.20 & 14 & 1.11 & 1.16 & 1.13 & 18 & 1.08 & 1.20 & $1.0^{\circ}$ & 1.22 \\
\hline $15^{\circ}$ & 1.19 & 17 & 1.10 & 1.15 & .13 & 1.19 & 1.08 & 1.16 & 1.1 & 1.25 \\
\hline $30^{\circ}$ & 15 & 11 & 1.09 & 1.20 & 1.13 & 1.18 & 1.10 & 1.18 & 1.13 & 1.23 \\
\hline $45^{\circ}$ & 1.15 & 1.09 & 1.14 & 1.18 & 1.16 & 1.19 & 1.14 & 1.17 & 1.19 & 1.23 \\
\hline $60^{\circ}$ & 1.17 & 1.05 & 1.13 & 1.15 & 1.11 & 1.19 & 1.17 & 1.17 & 1.18 & 1.21 \\
\hline $75^{\circ}$ & 1.16 & 1.16 & 1.11 & 1.20 & 1.09 & 1.22 & 1.07 & 1.18 & 1.23 & 1.20 \\
\hline $90^{\circ}$ & 1.23 & 1.19 & 1.08 & 1.15 & 1.16 & 1.19 & 1.08 & 1.17 & 1.28 & 1.20 \\
\hline $105^{\circ}$ & 1.25 & 1.19 & 1.10 & 1.16 & 1.14 & 1.11 & 1.11 & 1.18 & 1.25 & 1.17 \\
\hline $120^{\circ}$ & .18 & 1.15 & 1.1 & .11 & 1.14 & 1.10 & 1.11 & 1.12 & 1.25 & 1.17 \\
\hline $135^{\circ}$ & 1.05 & 1.16 & 1.08 & 1.08 & 1.08 & 1.11 & 1.1 & 1.16 & 1.19 & 1.20 \\
\hline 15 & 14 & 1.15 & 1.07 & 1.16 & 1.09 & 1.09 & 1.14 & 1.14 & 1.19 & 1.24 \\
\hline $165^{\circ}$ & 1.17 & 1.17 & 1.04 & 1.13 & 1.12 & 1.04 & 1.11 & 1.18 & 1.12 & 1.23 \\
\hline $180^{\circ}$ & 1.20 & 1.15 & 1.04 & 1.08 & 1.15 & 1.11 & & 1.19 & 2 & 1.20 \\
\hline $195^{\circ}$ & 1.21 & 1.17 & 1.06 & 1.11 & 1.07 & 1.08 & 1.01 & 1.12 & 1.15 & 1.18 \\
\hline $210^{\circ}$ & 1.19 & 1.13 & 1.05 & 1.08 & 1.10 & 1.09 & 1.08 & 1.13 & 1.20 & 1.16 \\
\hline $225^{\circ}$ & 1.14 & 1.17 & 1.11 & 1.08 & 1.19 & 1.08 & 1.12 & 1.14 & 1.22 & 1.17 \\
\hline $240^{\circ}$ & 1.12 & 1.15 & 1.11 & 1.15 & 1.16 & 1.13 & 1.12 & 1.15 & 1.24 & 1.20 \\
\hline $255^{\circ}$ & 1.14 & 1.18 & 1.12 & 1.11 & 1.15 & 1.13 & 1.13 & 1.18 & 1.24 & 1.20 \\
\hline $270^{\circ}$ & 1.12 & 1.14 & 1.09 & 1.15 & 1.20 & 1.16 & 1.13 & 1.19 & 1.23 & 1.23 \\
\hline $285^{\circ}$ & 1.24 & 1.07 & 1.08 & 1.19 & 1.18 & 1.19 & 1.19 & 1.21 & 1.30 & 1.25 \\
\hline $300^{\circ}$ & 1.21 & 1.10 & 1.11 & 1.18 & 1.13 & 1.13 & 1.20 & 1.20 & 1.24 & 1.23 \\
\hline $315^{\circ}$ & 1.08 & 1.10 & 1.10 & 1.16 & 1.13 & 1.13 & 1.14 & 1.17 & 1.21 & 1.24 \\
\hline $330^{\circ}$ & 1.07 & 1.15 & 1.10 & 1.18 & 1.12 & 1.18 & 1.17 & 1.19 & 1.16 & 1.27 \\
\hline $345^{\circ}$ & 1.13 & 1.17 & 1.09 & 1.15 & 1.09 & 1.19 & 1.14 & 1.19 & 1.16 & 1.27 \\
\hline
\end{tabular}

$\partial$ is Azimuth. Standing is standing position. Chair is chair sitting position. Cross is cross-legged sitting position. Leg-out is leg-out sitting position. Supine is supine position.

強く着衣面積增加率に現れることが示された。さらに、Tukey-test の結果は左前方と左後方の間が $\mathrm{p}<0.05$ を示し、着衣人体の非対称 の影䅉が強く認められた。仰卧位の場合には、大きな前後差は認め られなかった。したがって、前額面で非対称な胡座位や投げ足位の ような姿勢では、前後差や左右差が区分により認められるために、 人体を取囲む方位角にて着衣面㮴增加率を実測することが不可欠 である。さらに、着衣の折れや重なりを考慮すると立位や椅座位姿 勢でも人体を取囲む方位角にて実測をした方がよいと考えられる。

また、仰角の違いを検討した結果は、立位と胡座位、仰臥位の場 合には大きな前後差は認められなかった。一方、椅座位と投げ足位 の場合には、仰角 $60^{\circ}$ の実測值が仰角 $0^{\circ}$ と比較して大きい結果 となっている。椅座位姿勢は下肢部が前額面よりも前方に出た形態 であるが、仰角 $0^{\circ}$ の実測では、この部位が前額方向から実測した 写像には反映されるが、矢状方向から実測した写像には反映され難 いととが影響していると考元られる。したがって、人体の一部が矢 状方向に大きく突き出て前額面や正中面に対して非対称で体軸が 鉿直方向の椅座位や投げ足位のような姿勢では、異なる仰角にて着 衣面積増加率を実測することが不可欠である。

これらのことは、従来の研究や温熱環境指標を算出する際には、 着衣面積增加率を着衣熱抵抗值の線形式で求めてきたが、姿勢の違 いという側面から着衣条件を検討することが不可欠であることを 示すものといえる。 


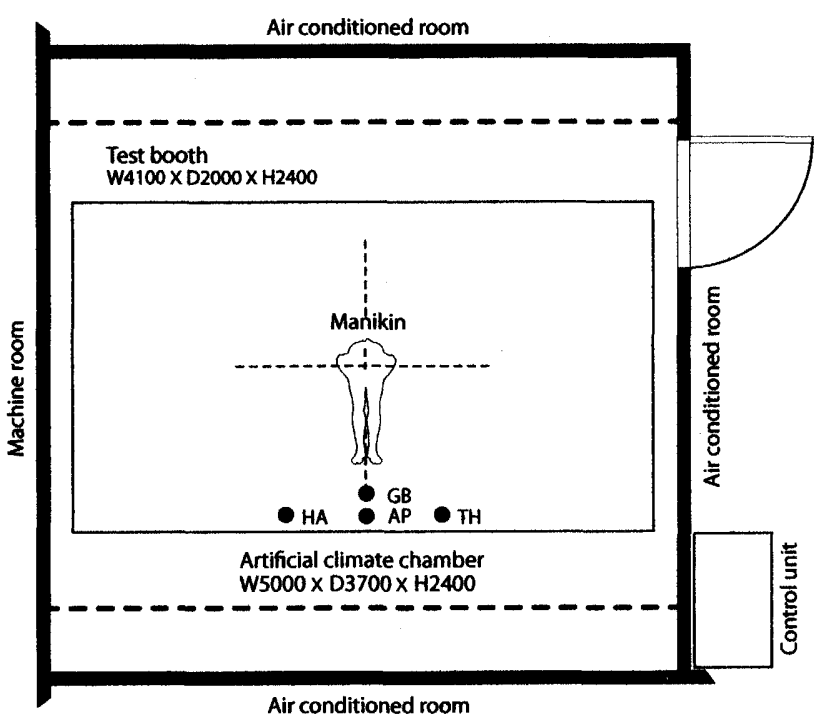

Fig. 3 Plan of test booth in artificial climate chamber. GB is globe thermometer. AP is aspirated psychrometer. HA is hotsphere anemometer. TH is air temperature in height.

\section{3. 着衣熱抵扰}

姿勢の違いが着衣熱抵抗值に与える影響を明らかにする実験を おこなった。着衣熱抵抗値は Seppanenn et al.(1972) ${ }^{17)}$ の理論に 基づいて算出した。なお、着衣熱抵抗値の算出に不可欠な着衣面積 増加率には、着衣面積增加率の実測により明らかにした姿勢別の平 均値を用いた。

\section{1 実雅計而}

実験はFig. 3 に示す人工気候室(タバイエスペック，TBRR$9 \mathrm{~A} 4 \mathrm{GX})$ 内に設置した布製のブース式の実験室を用いておこなっ た。

実験には、着衣面積増加率の測定と同じ肩と股、㯟の関節が可 動可能なサーマルマネキンを用いた。サーマルマネキンは、頭部 と胸部、背部、腹部、腰部、上膊部 (左右)、前膊部 (左右)、手部 (左右)、大腿部 (左右)、下腿部 (左右)、足部 (左右)の 17 部位 に分割され、部位毎に発熱量および表面温度の制御が可能である。 また、着衣条件も着衣面積增加率の測定と同じ冬季の住宅の居室内 における一般的な組み合わせの着衣 (松原ほか, 20001); 大和ほか ，200445) とした。サーマルマネキンへの衣服の着装には、表面に しわによる折れや重なりが偏って分布しないよう十分に留意した。 なお、通常の生活実態を考虑し、設定姿勢に移動させる際に発生す る着衣のしわや折れ、重なりなどは成り行きとした。加えて、実測 中には衣服の変更はおこなわず、着衣の状態は姿勢条件を通じて一 定とした。

実測は、Fig. 2 に示す立位と椅座位、胡座位、投げ足位、仰臥位 の姿勢別におこなった。立位姿勢の維持には、サーマルマネキンの 表面どうしの接触を除き、全ての表面を気流に開放できるように、 人工気候室の床面から $0.2 \mathrm{~m}$ 上方の位置にサーマルマネキンを熟架 した。椅座位と胡座位、投げ足位、仰臥位の姿勢の維持には、サー マルマネキンの表面どうしの接触を除き、全ての表面を気流に開放 できるように、人工気候室の床面から $0.8 \mathrm{~m}$ の位置に藤で編まれた
Table 4. Experimental conditions

\begin{tabular}{cccccc}
$\begin{array}{c}\text { Air } \\
\text { Temp. }\end{array}$ & $\begin{array}{c}\text { Air } \\
\text { Velocity }\end{array}$ & $\begin{array}{c}\text { Relative } \\
\text { Humidity }\end{array}$ & $\begin{array}{c}\text { Wall } \\
\text { Temp. }\end{array}$ & $\begin{array}{c}\text { Ceiling } \\
\text { Temp. }\end{array}$ & $\begin{array}{c}\text { Floor } \\
\text { Temp. }\end{array}$ \\
$\left({ }^{\circ} \mathrm{C}\right): \mathrm{T}_{\mathrm{a}}$ & $(\mathrm{m} / \mathrm{s}): \mathrm{V}_{\mathrm{a}}$ & $(\%): \mathrm{RH}$ & $\left({ }^{\circ} \mathrm{C}\right): \mathrm{T}_{\mathrm{w}}$ & $\left({ }^{\circ} \mathrm{C}\right): \mathrm{T}_{\mathrm{c}}$ & $\left({ }^{\circ} \mathrm{C}\right): \mathrm{T}_{\mathrm{f}}$ \\
\hline 16.0 & & & & & \\
18.0 & & & & & \\
20.0 & $<0.2$ & 50 & $=\mathrm{T}_{\mathrm{a}}$ & $=\mathrm{T}_{\mathrm{a}}$ & $=\mathrm{T}_{\mathrm{a}}$ \\
22.0 & & & & & \\
24.0 & & & & & \\
\hline
\end{tabular}

通気性のよい $1.0 \mathrm{~m} \times 2.0 \mathrm{~m}$ の床を設置し、その通気性のよい床面 上に直接姿勢をとった。加えて、椅座位姿勢の維持に使用した椅子 は、座面と背もたれの部分が藤で編まれた通気性のよいものを使用 した。これらの床と椅子は熱容量が小さく、サーマルマネキンに接 触する部分が少ないので、サーマルマネキンの表面は大気に開放さ れていると見做した。

設定温熱環境条件には、生活実態調査 (松原と澤島，1996 43); 坊 垣ほか，199844) より、冬期の室内で快適とされる温度帯から低温 域の範囲の条件設定をおこなった。Table 4 に温熱環境設定条件を 示す。温熱環境条件は気温が $16^{\circ} \mathrm{C}$ と $18^{\circ} \mathrm{C}, 20^{\circ} \mathrm{C}, 22^{\circ} \mathrm{C}, 24^{\circ} \mathrm{C}$ の 5 段階の壁表面温と気温が等しい均一環境条件とした。いずれの条 件とも風速 $(0.2 \mathrm{~m} / \mathrm{s}$ 以下の静稳な気流 ) と相对湿度 $(50 \% \mathrm{RH})$ は一 定とした。

温熱環境条件として気温と湿度、鉛直方向の気温分布、風速、室 内構成各面の表面温度を測定した。気温と湿度はアスマン通風乾湿 度計、風速は無指向性の熱球式風速計、鉛直方向の気温分布と室内 構成各面の表面温度とは $0.3 \mathrm{~mm} \phi \mathrm{T}$ 型熱電対で測定間隔 15 秒に て測定した。なお鉛直方向の気温分布は床表面から $170 \mathrm{~cm}$ までの 各 $10 \mathrm{~cm}$ 毎と天井表面を測定した。

サーマルマネキン側の条件として 17 分割の各部位の表面温と熱 損失量を測定した。表面温は $0.2 \mathrm{~mm} \phi \mathrm{T}$ 型熱電対で測定間隔 5 秒 にて測定した。熱損失量は消費電力量を測定間隔 5 秒にて測定した。

実験開始後、サーマルマネキンと周囲環境との間に熱平衡が成立 してから 90 分間サーマルマネキンを設定条件下に曝露した。サー マルマネキンの各部位の表面温度が $33^{\circ} \mathrm{C}$ 一定となるように、各部 位の電力量を制御した。設定温熱環境条件とサーマルマネキンから の熱損失が定常状態であることを確認した後、サーマルマネキンか らの熱損失量とマネキンの表面温度を測定した。実験終了前 30 分 間の熱損失量と皮盧温の実測値を解析に用いた。

\section{2 实給轺果および考察}

各実験条件中の気温は設定値士 $0.3^{\circ} \mathrm{C}$ 範囲内であった。相対湿 度はほぼ設定值士 $5 \%$ の範国内であった。床・天井表面温を含めた 垂直方向の気温分布はほぼ設定值士 $0.5^{\circ} \mathrm{C}$ 範囲内であった。風速 については実験を通じて $0.2 \mathrm{~m} / \mathrm{s}$ 以下であった。したがって、各実 験中の温熱環境は設定条件をほぼ満足していた。

裸体時の全熱抵抗值を Fig. 4 に、着衣時の全熱抵抗值を Fig. 5 に、 着衣熱抵抗値を Fig. 6 にそれぞれ示す。

裸体時の全熱抵抗值は、いずれの姿勢とも作用温度が高くなると 熱抵抗值も大きくなる傾向を示している。これは、作用温度が高く なるとサーマルマネキンの表面温度との差が小さくなり、自然対流 
の駆動力が小さくなる影䇾と考えられる。自然対流の駆動力が小さ くなるとサーマルマネキン表面を沿う上昇気流の流れが遅くなり、 温度境界層が厚くなることと整合した結果となっている。田辺ら $(1994)^{48)}$ の研究では裸体時の全熱抵抗値に温度依存性は認められ ない結果となっているが、本研究では大和ら $(2003)^{36)}$ 研究と同様 に温度差に依存する結果となっている。作用温度による熱抵抗值の 違いを ANCOVAにより比較した結果は $\mathrm{p}<0.01$ となり、作用温度 の違いによる影䇾が強く熱抵抗值に現れることが示された。姿勢に よる熱抵抗値の違いを ANCOVAにより比較した結果は $\mathrm{p}<0.01$ と なり、姿勢の違いによる影靁が強く熱抵抗値に現れることが示され た。さらに、Tukey-test の結果は、椅座位と胡座位、椅座位と仰卧位、 胡座位と投げ足位、投げ足位と仰臥位との間がそれぞれ $\mathrm{p}<0.01$ を 示し、これらの姿勢間には姿勢差の影變が強く認められた。

着衣時の全熱抵抗值は、いずれの姿乵とも作用温度が高くなる と熱抵抗値も大きくなる㑯向を示している。作用温度による熱抵 抗值の違いを ANCOVAにより比較した結果は $\mathrm{p}<0.01$ となり、作 用温度の違いによる影䈏が強く熱抵抗値に現れることが示された。 作用温度が高く、サーマルマネキンの表面温度との差が小さいほ ど、その影箘は著しい結果が示され、姿勢の違いによる熱抵抗值に 顕著な違いが認められる。また、床面や椅子面との接触をともな う姿勢においては、前述の着衣面㮴增加率の実測結果で示された着 衣面積增加率の高い姿勢ほど熟抵抗値の上昇率は高く熱抵抗値も より大きくなる頃向が強くなっている。衣服内空間の空気層の熱抵 抗や衣服の折れや重なりによる衣服の表面性状が形成する空気の 流れに対する表面の粗さなどが影謤していると考えられる。一方、 立位姿勢については前述の姿勢とは異なった㑯向を示している。着 衣面積增加率が仰卧位姿勢よりも小さい立位姿勢の場合には、衣服 内空間の体表面全体を包み込むように空気層が存在している。加え て、その空気層も大きな対流を誘因するほどの厚さではないと考え られる。このことは、着衣面積増加率が仰臥位姿勢よりも立位姿 勢の方が小さいことより明らかである。仰臥位姿勢の場合には体 表面の背面部分がほぼ床面と接触し、この体表部分では衣服内空 間の空気層がほとんど存在していない。したがって、床面との接 触部分の空気層の熱抵抗は着衣熱抵抗に大きな効果を及ぼしてい

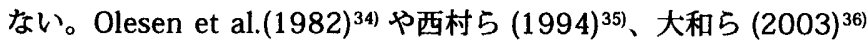
は、立位よりも椅座位姿勢の場合が熱抵抗值が小さいことを示して いるが、本研究でも同様な傾向を示している。姿勢による熱抵抗值 の違いを ANCOVA により比較した結果は $\mathrm{p}<0.01$ となり、姿勢の 違いによる影響が強く熱抵抗值に現れることが示された。さらに、 Tukey-test の結果は、投げ足位と仰臥位との間が $\mathrm{p}<0.05$ 、立位と 椅座位、立位と投り゙足位、椅座位と胡座位、椅座位と仰臥位、仰卧 位と椅座位との間がそれぞれ p $<0.01$ を示し、これらの姿勢間には 姿勢差の影響が強く認められた。

サーマルマネキンを用いた着衣熱抵抗値の実測については、着衣 外表面の表面温度を正確に求め、着衣外表面の表面温度が裸体表面 の表面温度よりも低いことを考虑する必要がある。しかし、本研究 では姿勢を除いた熱的な条件については全く同一なので、同一の温 熱環境条件においては裸体表面熱抵抗と着衣外表面熱抵抗との迬 いを検討しなくても、姿勢別に求めた着衣熱抵抗値の相対的な比較 をすることにより、一定の範囲内で姿勢の差を検討することが可能

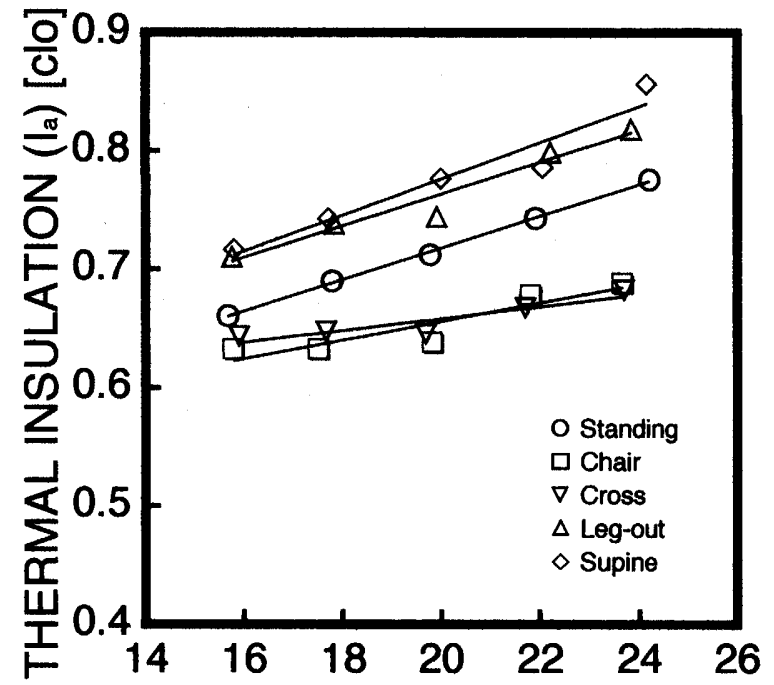

OPERATIVE TEMPERATURE $\left[{ }^{\circ} \mathrm{C}\right]$

Fig. 4 Relation between operative temperature and skin surface thermal insulation of naked manikin $\left(I_{a}\right)$. Standing is standing position. Chair is chair sitting position. Cross is cross-legged sitting position. Leg-out is leg-out sitting position. Supine is supine position.

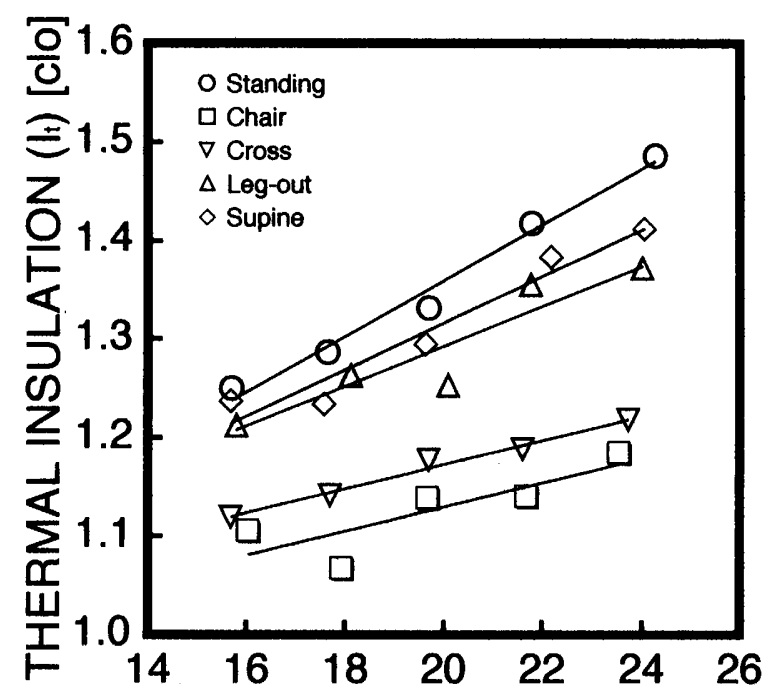

OPERATIVE TEMPERATURE $\left[{ }^{\circ} \mathrm{C}\right]$

Fig. 5 Relation between operative temperature and total thermal insulation of clothed manikin( $\left.I_{1}\right)$. Standing is standing position. Chair is chair sitting position. Cross is crosslegged sitting position. Leg-out is leg-out sitting position. Supine is supine position.

であると判断した。

着衣熱抵抗值は、いずれの姿勢とも作用温度が高くなると熱抵抗 值も大きくなる傾向を示している。前述のように、本研究の範囲で は裸体表面熱抵抗と着衣外表面熱抵抗との違いを正確には把握で きていない。サーマルマネキンを用いた実験にて、物理的な着衣熱 抵抗の真値を求めるには、着衣外表面の温度を正確に求めることが 不可欠である。したがって、作用温度の違いによる影響が必ずしも 明確にできたとはいえない。今後は、裸体表面熱抵抗と着衣外表面 熱抵抗との違いを検討し、着衣熱抵抗の環境温度への依存傾向を明 らかにする必要がある。 


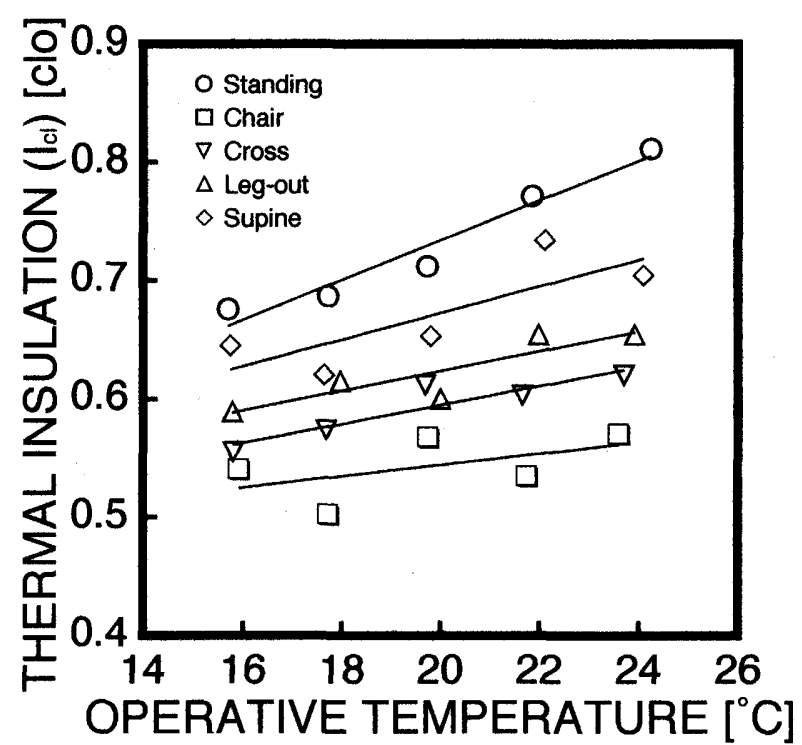

Fig. 6 Relation between operative temperature and basic thermal insulation of clothing $\left(\mathrm{I}_{\mathrm{cl}}\right)$. Standing is standing position. Chair is chair sitting position. Cross is cross-legged sitting position. Leg-out is leg-out sitting position. Supine is supine position.

作用温度が高く、サーマルマネキンの表面温度との差が小さいほ ど、姿勢の違いによる熱抵抗值に顕著な違いが認められる。前述の 裸体時の全熱抵抗值や着衣時の全熱抵抗值と同様な要因が働いて いると考えられる。立位姿勢の熱抵抗値が最も大きく、椅座位姿 勢の熱抵抗值が最も小さくなっている。Olesen et al.(1982) ${ }^{34)}$ 西村ら (1994) ${ }^{35)}$ の研究では、椅座位姿勢の着衣熱抵抗值は立位姿 勢よりも $15 \%$ 程度減少するとしている。温熱環境環境条件が最も 近似する作用温度 $24^{\circ} \mathrm{C}$ 程度での本研究の結果は、24\% 程度の隇少 を示している。西村ら (1994) ${ }^{35)}$ の研究では、着衣にスカートを用 い、椅座位姿勢の場合での着衣の被服面積の影響を指摘している。 本研究では、Olesen et al.(1982) ${ }^{34)}$ と同様にズボンを用いているが、 姿勢の違いが顕著に現れた。前述の着衣時の全熱抵抗値と同様に、 衣服内空間の空気層の熱抵抗や衣服の折れや重なりによる衣服の 表面性状が形成する空気の流れに対する表面の粗さなどが影響し ていると考えられる。すなわち、前述のように、同じ着衣でも姿勢 により着衣面積増加率は異なるので、姿勢別の着衣面積増加率を用 いて熱抵抗值を求める必要があるといえる。姿勢による熱抵抗值 の違いを ANCOVAにより比較した結果は $\mathrm{P}<0.01$ となり、姿勢の 違いによる影響が強く熱抵抗值に現れることが示された。さらに、 Tukey-test の結果は、椅座位と胡座位、投げ足位と仰臥位との間 がそれぞれ $\mathrm{p}<0.05$ 、立位と椅座位、立位と胡座位、立位と投げ足位、 椅座位と仰臥位、仰臥位と椅座位との間がそれぞれ $\mathrm{p}<0.01$ を示し、 これらの姿勢間には姿勢差の影響が強く認められた。

したがって、生活空間の温熱環境を評価する場合には、姿勢別の 着衣熱抵抗值を用いて温熱環境指標の算出をする必要がある。

\section{4. おわりに}

着衣面積增加率と着衣熱抵抗値に及ぼす姿勢の影響を明らかに することを目的として、立位と椅座位、胡座位、投げ足位、仰臥位 姿勢におけるサーマルマネキンを用いた実験をおこなった。
1) 本研究の着衣における各姿勢の着衣面積増加率は、立位で 1.15、椅座位で 1.12、胡座位で 1.14、投げ足位で 1.14、仰臥 位で 1.21 を得た。

2）異なる仰角で人体を取囲む方位角にて着衣面積増加率の実测を することが不可欠であることを明確にした。従来の着衣面積增 加率の実測方法では実測值に姿勢の効果を表現し難い。

3）衣服の折れや重なりによる衣服の表面性状の変化や衣服内空間 の空気層の変化などが影響し、姿勢の違いが着衣面積増加率に 強く現れること示した。従来の着衣面積増加率の算出式では算 定值に姿勢の効果を表現できない。

4) 姿勢によって着衣熱抵抗值が異なることを明確にした。従来の 着衣熱抵抗値の実測方法や算定方法では、姿勢の効果を表現で きない。

5) 温熱環境の設計や評価をする場合には、姿勢の違いを考虐して 着衣条件を検討し、着衣熱抵抗値を定めることが不可久である ことを明確にした。

\section{参考文献}

1）松原斎樹，加藤真理子，藏澄美仁，大和義昭，松原小夜子，下村孝：京都市 近郊における住宅居住者の居間での休息姿勢, 一その体温調節行動的側 面一，日本生気象学会雑誌，37(2), pp.73-85, 2000.8

2）大和義昭，松原斎樹，藏澄美仁：京都市近郊地域における夏期の住宅居住 者の居間での休息姿勢，一住宅種別，年齡層別による違いに関する考察 一，日本生気象学会雑誌，42(4), pp.111-122, 2005a.12

3）大和義昭, 松原斎樹，藏澄美仁 : 京都市近辺地域におけるる冬期の住宅居住 者の居間での休息姿勢，一住宅種別，年粭層別による迬いに関する考察 一，日本生気象学会雑誌，42(4), pp.123-135, 2005b.12

4）藏澄美仁，大和義昭，山本志津恵，松原斎樹：姿勢の違いを考慮した平均 皮湿温算出法に関する研究，日本生気象学会雑誌，34(4), pp.101-112, 1997.12

5）藏澄美仁，松原斎樹，鳴海大典，屒野和雄，土川忠浩，堀越哲美：姿勢の 違いが体感温度に与える影響に関する研究，日本生気象学会雑誌，35(1) pp.35-44, 1998a.4

6）藏澄美仁，松原斎樹，大和義昭，山本志津惠，長井秀樹，鳴海大典：姿勢 の違いが伝導熱交換量に与える影饝に関する研究，日本生気象学会雑誌， 35(2), pp.85-94, 1998b.8

7）藏澄美仁, 松原斎樹，古川掄子, 藤原三和子, 上麻美, 植木弥生, 長井秀樹 ，山本志津恵：姿勢の違いと日本人の平均皮病温算出法，日本生気象学会 雑誌, 35(4), pp.121-132, 1998c.12

8）藏澄美仁，山本志津恵，松原斎樹 : 姿勢の違いと日本人青年女性の安静時 代謝量，日本生気象学会雑誌，36(1), pp.21-29, 1999a.4

9）藏澄美仁，松原斎樹，長井秀樹，古川倫子, 藤原三和子, 上麻美, 植木弥生 ，山本志津恵 : 温熱環境評価と熱伝導に関する研究，空気調和・衛生工学 会論文集, 72,pp.23-34,1999b.1

10）藏澄美仁, 松原斎樹, 植木弥生, 上麻美, 長井秀樹, 山本志津恵, 古川倫 子、藤原三和子 : 休加温環境における姿勢の違いが人体へ及ぼす影算，日 本生気象学会雑誌.36(1), pp.3-19, 1999c.4

11）藏澄美仁，中村亮，松原斎樹 : 作用温度 $28^{\circ} \mathrm{C}$ における日本人青年の安 静時代謝量に及ぼす姿勢の影䈏，日本生気象学会雑誌，37(1), pp.27-37。 2000.4

12）藏澄美仁，土川忠浩，大和義昭，角谷孝一郎，松原斎樹，堀越哲美：姿 勢と人体の有効対流面積率に関する研究，日本生気象学会雑誌，40(1) pp.3-13, 2003b.5

13）藏澄美仁，土川忠浩，角谷孝一郎，大和義昭，鳥居孝行，松原斎樹，堀越 哲美：対流伝熱面稓を考慮した平均皮间温に関する研究，一正座位，胡座 位，横座位，立て滕位，投げ足位，側臥位，仰臥位姿勢の算出法一, 日本建 
築学会環境系論文集 , 585, pp.19-26, 2004.11

14）藏澄美仁，土川忠浩，大和義昭，中谷岳史，松原斎樹，䏱越哲美：放射冷 暖房空間における人体の放射熱収支に関する研究，横座位・投げ足位・ 側臥位 - 仰臥位の人体の有効放射面積と人体の矩形面との間の形態係数 , 空気調和・衛生工学会論文集，97, pp.1-14, 2005.4

15) Kurazumi, Y., Tuchikawa, T., Torii, T., Kakutani, K., Matsubara, N., Horikoshi, T. : Weighting coefficients for calculating mean skin temperature when considerating convective heat transfer areas, Journal of the Human-Environmental System, 7(1), pp.19-28, 2004

16)Kurazumi, Y., Tsuchikawa, T., Matsubara, N., Horikoshi, T. : Convection heat transfer area of the human body, European Journal of Applied Physiology, 93(3), pp.273-285, 2004.11

17) Seppanen, O., McNall, P.E., Munson, D.M. : Thermal insulating for typical indoor clothing ensembles, ASHRAE Transactions, 78(1), pp.120-130, 1972

18) Sprague, C.H., Munson, D.M. : A composite ensemble method for estimating thermal insulating values of clothing, ASHRAE Transactions, 80(1), pp.20-129, 1974

19) Mcllough, E.A., Jones, B.W., Zbikowski, P.J. : The effect of garment design on the thermal insulation values of clothing, ASHRAE Transactions, 89(2A), pp.327-353, 1983)

20) Mcllough, E.A., Jones, B.W., Huck, J. : A Comprehensive Data Base For Estimating Clothing Insulation, ASHRAE Transactions, 91 (2), pp.29-47, 1985

21) Olesen, B.W. : A new simpler method for estimating the thermal insulation of a clothig ensmble, ASHRAE Transactions, 91(2), pp.478-492, 1985

22) 三平和雄，大野静枝 : サーマルマネキンによる着衣の clo 值測定、家政学 雑誌，28(3), pp.216-222, 1977

23）花田募代子，三平和雄，大幡久仁子：䀦人用下着類の勲抵抗の計測に関 する研究，日本絨維製品消费科学会誌，22(10), pp.430-437, 1981

24）花田嘉代子，三平和雄，佐藤由美：男子用下着類の熱抵抗の計測に関す 万研究，日本織維製品消费科学会誌，24(8), pp.363-369, 1983

25）花田䓵代子，三平和雄：着衣の熱特性に関する研究，人間工学，21(3), pp.101-107, 1985

26) Mihira, K., Hanada, K. : A study of clo values measurment using thermal manikin, Nippon Ifuku Gakkaishi, 34(2), pp.16-23, 1991

27）佐古井智紀，長野克則，持田徹，䲴會一寅 : 衣服の保温性能評価法に関す る基整的研究，空気調和・衛星工学会論文集，77, pp.95-107, 2000.4

28）花田嘉代子 : 着农の局所別熱抵抗に関する研究 (第二報), - ワンピースウ エアについて -, 日本䋃維製品消费科学会誌，20(8), pp.305-310, 1979b

29）岩崎房子，田村照子：サーマルマネキンによる被服の熱抵抗に関する研 究 (第二報), 一被服面積と熱抵抗の関係-, 日本文化女子大学紀要，16, pp.231-239, 1985

30）岩崎房子，田村照子：サーマルマネキンによる被服の熱抵抗に関する研 究 (第三報), 一被服下空気層と熱抵抗の関係 -, 日本文化女子大学紀要， 18. pp.22-33, 1987

31) 雷田明美, 宮本征一，堀越哲美 : 着衣のゆとり度が立位姿勢の人体投射面 積に及ぼす影䈏，日本建築学会大会学術講演梗概集，pp.409-410, 1998

32) 渡邊慎一，米田喜正，富田明美，堀越哲美 : 気流および着衣のゆとりがク

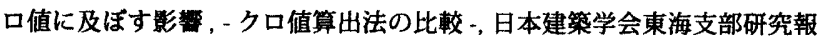
告書, 38, pp.541-544, 2000

33）花田嘉代子 : 着衣局所別熱抵抗に関する研究 (第一報), - スポーツウェア について -, 日本織維製品消費科学会誌, 20(7), pp.273-279, 1979a

34) Olesen, B.W., Silwinska, E., Madsen, T.L., Fanger, P.O. : Effect of body posture and activity on the thermal insulation of clothing ; Measurements by a movable thermal manikin, ASHRAE Transactions, 88(2), pp.791-805, 1982

35）西村美加, 田辺新一, 長谷部ヤエ : 姿勢による着衣熱抵抗の変化, The Annals of Physiological Anthropology, 13(6), pp.337-343, 1994.11
36) 大和義昭，藏澄美仁，橋田美奈，鳥居孝行，松原斎樹 : 姿勢の違いと着衣 熱抵抗に関する研究，人間と生活環境，10(2),pp.108-116,2003.11

37) 渡邊慎一，内田博恵，堀越哲美，冨田明美，石井仁：気温・風速および被 服のゆとりが着衣熱抵抗に及ぼす影䈏，日本建築学会大会学術講演梗概 集, pp.391-392, 1999

38) Fanger, P.O. : Thermal comfort, Danish Technical Press, Copenhagen, Denmark, 1970

39) Kakitsuba, N., Michna, H., Mekjavic, I.B. : Clothing surface area as related to body volume and clothing microenvironment volume, Aviation, Space, and Environmental Medicine, 58(5), pp.411-416, 1987

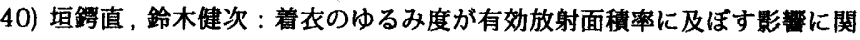
する研究，日本建築学会計画系論文集，500,pp.37-41，1997.10

41) 宮本征一，冨田明㶫：温熱環境要素である着衣熱抵抗の定鲳的把握に関 する検討， - 着衣による有好放射面積事の増加について -, 日本建築学会東 海支部研究報告集，38, pp.537-540, 2000

42) Kakitsuba, N., Mekjavic, I.B. : Determining the rate of body heat storage by incorporating body composition, Aviation, Space, and Environmental Medicine, 58(4), pp.301-307, 1987

43）松原斎樹，澤島智明 : 京都市近郊における冬期住宅居間の熱璱境と居住 者の住まい方に関する事例研究，〜暖房機器の使用状況の特徴とだん 5ん時の起居粎式〜，日本建築学会計画系論文報告集，488, pp.75-84, 1996.10

44）坊垣和明，澤地孝男，吉野博，跲木害三，赤林伸一，井上隆，大野秀夫 ，松原斎㩐，林撤夫，森田大：夏期および冬期の居住室室温とその地域 性に関する研究，一全国的拥查に基づく住宅のエネルギー消费とライフ スタイルに関する研究一第 2 報，日本建学会計画系論文報告集，505， pp.23-30, 1998.3

45) 大和義昭，松原斎樹，藏澄美仁 : 京都京市および近郊の住宅における着衣 量の実態に関する調查研究，日本建築学会即境系論文集，595,pp.25-31, 2005.9

46) ISO : ISO-9920 Ergonomics of thermal environment -Estimation of the thermal insulation and evaporative resistance of a clothing ensemble, ISO, 1995

47) Fanger, P.O., Angelius, O., Jensen, P.K. : Radiation data for the human body, ASHRAE Transactions, 76-II, pp.338-373, 1970

48）田辺新一，長谷部ヤエ, 西村美加：サーマルマネキンによる基礎着衣熱 抵抗の測定法比較，織維学会誌, 50(4), pp.180-187, 1994

(2005年10月 7 日原稿受理，2006年 3 月15日採用決定） 